Suvremena psihologija 21 (2018), 1, 43-56

Izvorni znanstveni članak - UDK 159.922.1

DOI: $10.21465 / 2018-$ SP-211-03

\title{
POSREDUJUĆA ULOGA SEKSUALNOG ZADOVOLJSTVA IZMEĐU DIMENZIJA PRIVRŽENOSTI I ZADOVOLJSTVA PARTNERSKOM VEZOM
}

\author{
Vesna Antičević \\ Sveučilište u Splitu, Sveučilišni odjel zdravstvenih studija \\ Ruđera Boškovića 35, 21000 Split \\ vesna.anticevic@ozs.unist.hr
}

\begin{abstract}
Sažetak
U ovom radu je ispitana posredujuća uloga seksualnoga zadovoljstva u odnosu između dimenzija privrženosti i zadovoljstva vezom.

Modificirani inventar iskustava u bliskim vezama (Kamenov i Jelić, 2003) i Nova skala seksualnog zadovoljstva (Štulhofer i Buško, 2008) primijenjeni su na prigodnom uzorku dobivenom na 255 muškaraca i 257 žena metodom "snježne grude". Rezultati upućuju na značajno više vrijednosti na dimenziji anksioznosti kod žena te na značajno više vrijednosti na dimenziji izbjegavanja muškaraca. Obje dimenzije privrženosti negativno su povezane sa seksualnim zadovoljstvom i zadovoljstvom vezom, pri čemu je utvrđen posredujući učinak seksualnog zadovoljstva između obje dimenzije privrženosti i zadovoljstva vezom kod muškaraca i žena. Na dimenziji izbjegavanja utvrđen je izraženiji učinak na seksualno zadovoljstvo kod oba roda, dok je na dimenziji anksioznosti utvrđen izravni učinak samo na zadovoljstvo vezom žena.
\end{abstract}

Ključne riječi: Seksualno zadovoljstvo; zadovoljstvo vezom; privrženost

\section{UVOD}

Teorija privrženosti (Bowlby, 1969) pruža koristan teorijski okvir za izučavanje različitih međuljudskih odnosa, pa tako i odnosa u partnerskim vezama. Prema teoriji privrženosti, ljudi u partnerskim vezama razvijaju mentalne reprezentacije o emocionalnoj dostupnosti partnera temeljem kojih oblikuju kognitivne i bihevioralne odgovore prema njima (Russel, Baker i McNulty, 2013). Hazan i Shaver (1987) su pronašli da većina ljudi (oko 60\%) iskazuje sigurnu privrženost u svojim partnerskim vezama koja se temelji na međusobnom razumijevanju, uz zadržavanje vlastite neovisnosti o partneru. Manji broj ljudi iskazuje obrasce nesigurne privrženosti, pri čemu razvijaju jedan od tri obrasca doživljavanja. U prvom slučaju 
osjećaju strah od odbacivanja te se pretjerano vezuju za partnere i razvijaju ovisnost o njima (anksiozni stil privrženosti). Ako osjećaju nelagodu u bliskim odnosima, tada izbjegavaju emocionalno vezivanje i trude se zadržati neovisnost o partneru (izbjegavajući stil privrženosti). Konačno, neki ljudi istodobno žele bliske odnose, ali ih izbjegavaju zbog straha od mogućeg odbacivanja od partnera (plašljivi stil privrženosti). U odnosu na kategorijalni model koji pretpostavlja da svaki čovjek pripada jednoj kategoriji privrženosti, privrženost se bolje može opisati dimenzionalnim pristupom koji omogućuje određivanja položaja pojedinca na svakoj dimenziji (anksioznosti i izbjegavanja). Pri tome, osobe koje imaju niske rezultate na obje dimenzije najčešće su sigurno privržene u bliskim odnosima, dok su one s visokim rezultatima nesigurno privržene (Brenan, Clark i Shaver, 1998). Na osnovi rezultata na dimenzijama, moguće je odrediti pripadnost kategoriji. Ako je rezultat pojedinca na dimenziji anksioznosti viši od granične vrijednosti, tada kod njega dominira anksiozni stil, a ako je rezultat iznad granične vrijednosti na dimenziji izbjegavanja, kod tog pojedinca prevladava izbjegavajući stil privrženosti. Ako su rezultati na obje dimenzije iznad graničnih vrijednosti, tada se može pretpostaviti da se radi o plašljivom stilu privrženosti. Sigurno privrženi ljudi češće su zadovoljniji svojim partnerskim vezama u odnosu na nesigurno privržene (Ayenew, 2016, Li i Chan, 2012).

Osim načina iskazivanja privrženog ponašanja, na zadovoljstvo partnerskom vezom utječe i seksualno zadovoljstvo (Karney i Bradbury, 1995), tj. emocionalni odgovori koji su rezultat subjektivne evaluacije seksualnih odnosa (Lawrance i Byers, 1995). Osobe koje su zadovoljne svojim seksualnim odnosima, zadovoljnije su svojim vezama i kvalitetom bračnih odnosa te im seksualno zadovoljstvo pomaže u prevladavanju bračnih nesuglasica (Yeh, Lorenz, Wickrama, Conger i Elder, 2006; Mark, Milhausen i Maitland, 2013; MacNeil i Byers, 2005; Sprecher i Cate, 2004). Iz perspektive teorije privrženosti (Bowlby, 1969), privrženost, seksualnost i brižnost međusobno su povezani i integrirani u svim fazama seksualnog odgovora te određuju stupanj seksualnog zadovoljstva ljudi. Kao rezultat karakteristika nesigurne privrženosti i odabira seksualnih ponašanja kojima nastoje zadovoljiti ciljeve svojega sustava privrženosti (prevenirati odbacivanje odnosno izbjeći emocionalnu bliskost), osobe s višim stupnjevima anksiozne i izbjegavajuće privrženosti češće su nezadovoljne svojim partnerskim vezama i iskazuju manje seksualno zadovoljstvo (Birnbaum, 2007; Milad, Ottenberger i Artigas, 2014; Péloquin, Brassard, Delisle i Bédard, 2013) u odnosu na sigurno privržene osobe. Različiti stupnjevi aktivacije sustava privrženosti često rezultiraju razlikama u ciljevima privrženog ponašanja te razlikama u seksualnoj motivaciji, seksualnim ponašanjima i ishodima seksualne aktivnosti (Davis, Shaver i Vernon, 2004; Schachner i Shaver, 2004) (Tablica 1).

S obzirom na to da su viši stupnjevi nesigurne privrženosti negativno povezani sa seksualnim zadovoljstvom i sa zadovoljstvom vezom, otvara se pitanje može li utjecaj viših stupnjeva anksiozne i izbjegavajuće privrženosti na zadovoljstvo vezom biti posredovan smanjenim seksualnim zadovoljstvom? Pregledom dostupne 
Tablica 1. Ciljevi sustava privrženosti i njihova povezanost sa seksualnim motivima i ishodima seksualnog ponašanja

\begin{tabular}{|c|c|c|c|}
\hline & \multicolumn{3}{|c|}{$\begin{array}{c}\text { STILOVI PRIVRŽENOSTI/ } \\
\text { STUPNJEVI AKTIVACIJE SUSTAVA PRIVRŽENOSTI }\end{array}$} \\
\hline & $\begin{array}{l}\text { Sigurna privrženost } \\
\text { "Normalni” stupanj } \\
\text { aktivacije }\end{array}$ & $\begin{array}{l}\text { Anksiozna privrženost } \\
\text { Hiperaktivacija }\end{array}$ & $\begin{array}{l}\text { Izbjegavajuća privrženost } \\
\text { Deaktivacija }\end{array}$ \\
\hline 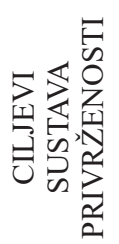 & $\begin{array}{l}\text { zadržavanje međuovisnosti } \\
\text { i intimnosti u partnerskim } \\
\text { odnosima koji već postoje. }\end{array}$ & $\begin{array}{l}\text { pridobivanje i zadržavanje } \\
\text { sigurnosti koju omogućuje } \\
\text { blizina partnera. }\end{array}$ & $\begin{array}{l}\text { održavanje emocionalne } \\
\text { distance i kontrole u par- } \\
\text { tnerskim odnosima. }\end{array}$ \\
\hline 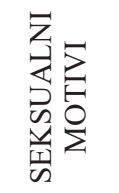 & $\begin{array}{l}\text { održavanje dugotrajnih } \\
\text { emocionalnih veza i povje- } \\
\text { renja. }\end{array}$ & $\begin{array}{l}\text { pridobivanje partnerove } \\
\text { ljubavi, podređivanje par- } \\
\text { tnerovim željama, preveni- } \\
\text { ranje napuštanja od strane } \\
\text { partnera. }\end{array}$ & $\begin{array}{l}\text { fizičko zadovoljstvo, ma- } \\
\text { nipulacija, impresioniranje } \\
\text { drugih, izbjegavanje inti- } \\
\text { mnosti, podizanje seksual- } \\
\text { nog samopoštovanja. }\end{array}$ \\
\hline 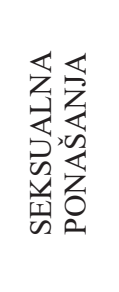 & $\begin{array}{l}\text { preferiranje seksualnih } \\
\text { aktivnosti u dugotrajnim } \\
\text { monogamnim vezama, } \\
\text { otvorena komunikacija o } \\
\text { seksu. }\end{array}$ & $\begin{array}{l}\text { češće pristajanje na neže- } \\
\text { ljeni seks, ranije stupanje } \\
\text { u seksualne odnose, rjeđa } \\
\text { uporaba kontracepcije, pre- } \\
\text { okupiranost seksom. }\end{array}$ & $\begin{array}{l}\text { "one-night” seks bez emo- } \\
\text { cionalnog vezivanja, uklju- } \\
\text { čivanje u neformalne seksu- } \\
\text { alne aktivnosti sa strancima, } \\
\text { kasnije stupanje u seksualne } \\
\text { odnose, izbjegavanje seksu- } \\
\text { alnih odnosa s partnerom, } \\
\text { čeśća masturbacija. }\end{array}$ \\
\hline 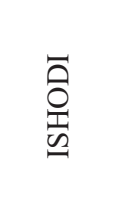 & $\begin{array}{l}\text { više seksualno samopo- } \\
\text { štovanje i zadovoljstvo } \\
\text { seksualnim aktivnostima u } \\
\text { dugotrajnim vezama. }\end{array}$ & $\begin{array}{l}\text { nisko seksualno samopošto- } \\
\text { vanje, manje seksualno za- } \\
\text { dovoljstvo i viša seksualna } \\
\text { anksioznost, ambivalentne } \\
\text { reakcije prema seksualnim } \\
\text { iskustvima. }\end{array}$ & $\begin{array}{l}\text { nisko seksualno samopo- } \\
\text { štovanje, averzivni stavovi } \\
\text { prema seksualnosti, manje } \\
\text { seksualno zadovoljstvo u } \\
\text { stalnim vezama. }\end{array}$ \\
\hline
\end{tabular}

literature, pronađen je mali broj znanstvenih članaka koji ispituju povezanost nesigurne privrženosti sa seksualnim i bračnim zadovoljstvom. Tako na uzorku bračnih parova Butzer i Campbell (2008) pronalaze izraženiji posredujući učinak anksiozne privrženosti između seksualnog zadovoljstva i zadovoljstva vezom, u odnosu na izbjegavajuću privrženosti. U drugom istraživanju je utvrđeno da je odnos između nesigurne privrženosti i zadovoljstva brakom posredovan očekivanjima o dostupnosti partnera (Little, McNulty i Russell, 2010). U istraživanju na ženama, Birnbaum (2007) je utvrdila posredujući učinak seksualnog zadovoljstva samo između anksiozne privrženosti i zadovoljstva vezom. U ovom smo istraživanju željeli provjeriti mogući doprinos seksualnog zadovoljstva objašnjenju odnosa između nesigurne 
privrženosti i zadovoljstva vezom. Temeljem prijašnjih nalaza o rodnim razlikama u seksualnosti (Birnbaum, 2007) i stilovima privrženosti (Del Guidice, 2011), pretpostavljeno je da bi posredujući učinci seksualnog zadovoljstva između privrženosti i zadovoljstva vezom mogli biti drugačiji kod muškaraca i žena pa su u ovom istraživanju uključeni sudionici oba roda te je definiran sljedeći istraživački cilj.

\section{CILJ}

U ovom istraživanju ispitivana je posredujuća uloga seksualnoga zadovoljstva u odnosu između dimenzija privrženosti i zadovoljstva vezom kod muškaraca i žena.

\section{METODE}

\section{Sudionici}

Istraživanjem je obuhvaćeno 512 hrvatskih građana oba roda $(\mathrm{Nm}=255$ i Nž $=$ 257) koji su, u vrijeme ispitivanja, bili u bračnoj $(59,4 \%)$ ili izvanbračnoj $(40,6 \%)$ partnerskoj vezi. Prosječna dob iznosila je 36,1 godina, u rasponu od 19 do 65 godina. Prosječno trajanje veze iznosilo je 11,2 godina, pri čemu je najkraća veza trajala 3 mjeseca, a najduža 47 godina.

\section{Mjerni instrumenti}

Modificirani inventar iskustava u bliskim vezama (Kamenov i Jelić, 2003) je skraćeni hrvatski oblik skale Experiences in Close Relationships (ECR) (Brennan i sur., 1998), koja je namijenjena za mjerenje stilova odnosno dimenzija privrženosti. Korišten je skraćeni oblik skale, koji sadrži 18 čestica (9 čestica za ispitivanje anksiozne i 9 čestica za ispitivanje izbjegavajuće privrženosti). Rezultati sudionika prikazani su dimenzionalno, na skalama anksioznosti i izbjegavanja. Sudionici su odgovarali na skali od 7 stupnjeva (od 1-u potpunosti se ne slažem do 7-u potpunosti se slažem). Viši rezultati na skalama upućuju na više stupnjeve anksiozne odnosno izbjegavajuće privrženosti. U ovom istraživanju koeficijenti pouzdanosti (Cronbach Alpha) iznose: skala anksioznosti 0,82, a skala izbjegavanja 0,81. Provedbom faktorske analize utvrđeno je postojanje 4 faktora prema Kaiserovu kriteriju, kojima je objašnjeno 54,58 \% varijance. S obzirom na pripadajući nagib scree plot prikaza svih pripadajućih faktora, te na ranije analize istog upitnika na drugim uzorcima, zadržana su 2 faktora kojima je objašnjeno 42,88 \% varijance. Dvofaktorska struktura analizirana je u nastavku ortogonalnom rotacijom faktora varimax metodom. Svojstvene vrijednosti tih dvaju faktora na pripadajućim česticama analizirane su nakon rotacije, te je utvrđeno da zasićenja na svih 18 čestica upućuju na 
sadržajnu strukturu faktora izbjegavajuće i anksiozne privrženosti, odgovarajuću onoj u originalnom opisu faktorske strukture skale.

Nova skala seksualnoga zadovoljstva (Štulhofer i Buško, 2008) instrument je za procjenu seksualnoga zadovoljstva. U ovom istraživanju je korištena kraća verzija skale (12 čestica) čija pouzdanost iznosi $\alpha=0,93$ (Štulhofer i Buško, 2008). Sudionici su odgovarali na skali od 5 stupnjeva (od 1 -nimalo zadovoljan/na, do 5 -potpuno zadovoljan/na), pri čemu je maksimalan rezultat koji sudionik može postići 60 . Stupanj seksualnoga zadovoljstva određivan je ukupnim rezultatom na skali. Viš̀ rezultat upućuje na viši stupanj seksualnoga zadovoljstva. Koeficijent pouzdanosti Cronbach $\alpha$ u ovom istraživanju iznosi 0,85 . Analiza faktorske strukture upitnika utvrdila je postojanje dvokomponentne strukture koja objašnjava 58,98\% ukupne varijance. S obzirom na veliki pad u nagibu scree plot prikaza karakterističnih vrijednosti svih ekstrahiranih faktora između prvog faktora (koji prije rotacije objašnjava 49,59\% ukupne varijance) i drugog faktora (koji prije rotacije objašnjava $9,83 \%$ ukupne varijance), odlučili smo zadržati jednofaktorsku strukturu. Također, analizom faktorskih opterećenja u slučaju zadržavanja dvofaktorske strukture otežana je mogućnost interpretacije faktora, a zadržavanjem jednog faktora interpretacija je moguća s obzirom na visoka zasićenja svih čestica. Takvom strukturom, nakon rotacije varimax metodom, objašnjeno je ukupno 49,59\% varijance.

Upitnik općih podataka sadržavao je pitanja o dobi, rodu, partnerskom statusu (je li u vezi ili nije). Za određivanje stupnja zadovoljstva vezom korišteno je pitanje "Koliko ste općenito zadovoljni svojom partnerskom vezom?", pri čemu su sudionici odgovarali na skali od 1 (uopće nisam zadovoljan/na) do 5 (u potpunosti sam zadovoljan/na).

\section{Postupak}

Za prikupljanje podataka primijenjena je metoda "snježne grude" (Erickson, 1979) na sljedeći način: primjena na početnom studentskom uzorku $(\mathrm{N}=139)$ obavljena je za vrijeme nastave. Potom su studenti zamoljeni da među svojim poznanicima odaberu najmanje četiri osobe muškog i ženskog roda koje bi bile voljne sudjelovati u istraživanju. Studenti su također zamolili na taj način odabrane osobe da navedu nekoliko svojih poznanika, u istim dobnim rasponima, koji bi bili voljni sudjelovati u istraživanju. Nakon pristanka tih novih kontakata, studenti bi im dostavili upitnike koje su, nakon primjene, u zatvorenim omotnicama vratili istraživaču. Ovo istraživanje odobreno je od Etičkog povjerenstva Filozofskog fakulteta u Zagrebu.

\section{REZULTATI}

Deskriptivni parametri u Tablici 2 upućuju na izraženiju anksioznu privrženost žena, te izraženiju izbjegavajuću privrženost muškaraca. 
Tablica 2. Razlike u dimenzijama privrženosti, seksualnom zadovoljstvu i zadovoljstvu vezom između muškaraca $(N=255)$ i žena $(N=257)$

\begin{tabular}{llcccc}
\hline Varijable & Rod & $M$ & $S D$ & Raspon & $t$-test (t) \\
\hline Anksiozna privrženost & Muškarci & 24,35 & 11,04 & $9-52$ & $2,46, \mathrm{p}<0,05$ \\
& Žene & 26,81 & 11,59 & $9-62$ & \\
Izbjegavajuća privrženost & Muškarci & 25,12 & 10,44 & $9-62$ & $4,17, \mathrm{p}<0,01$ \\
& Žene & 21,44 & 9,5 & $9-51$ & \\
\multirow{2}{*}{ Seksualno zadovoljstvo } & Muškarci & 48,1 & 8,55 & $12-60$ & $0,79, \mathrm{p}>0,05$ \\
& Žene & 47,47 & 9,46 & $12-60$ & \\
\multirow{2}{*}{ Zadovoljstvo vezom } & Muškarci & 4,2 & 0,79 & $1-5$ & $1,37, \mathrm{p}>0,05$ \\
\multirow{2}{*}{ Trajanje veze } & Žene & 4,1 & 0,86 & $1-5$ & \\
& Muškarci & 11,3 & 9,07 & $1-39$ & $0,11, \mathrm{p}>0,05$ \\
& Žene & 11,2 & 9,52 & $1-40$ & \\
\hline
\end{tabular}

Iz korelacijske matrice (Tablica 3) vidljivo je da između svih ispitivanih varijabli postoje značajne povezanosti, pri čemu su obrasci povezanosti vrlo slični kod muškaraca i žena.

Obje dimenzije privrženosti (anksiozna i izbjegavajuća) značajno su negativno povezane sa seksualnim zadovoljstvom i sa zadovoljstvom partnerskom vezom, pri čemu su stupnjevi povezanosti kod muškaraca i žena nešto viši kod izbjegavajuće privrženosti nego kod anksiozne privrženosti (Tablica 3).

Za odgovor na istraživački problem korištena je analiza traga (Kenny, Kashy i Bolger, 1998), u kojoj su dimenzije nesigurne privrženosti bile prediktorske varijable, seksualno zadovoljstvo medijacijska, a zadovoljstvo vezom kriterijska varijabla.

Regresijskim analizama je utvrđeno da anksiozna privrženost ima statistički neznačajan $(\beta=-0,1, p>0,05)$, a izbjegavajuća privrženost $(\beta=-0,19, p<0,05)$

Tablica 3. Povezanost između dimenzija privrženosti, seksualnog zadovoljstva i zadovoljstva vezom muškaraca (iznad dijagonale) $(N=255)$ i žena (ispod dijagonale) $(N=257)$

\begin{tabular}{lcccc}
\hline & $\begin{array}{c}\text { Anksiozna } \\
\text { privrženost }\end{array}$ & $\begin{array}{c}\text { Izbjegavajuća } \\
\text { privrženost }\end{array}$ & $\begin{array}{c}\text { Seksualno } \\
\text { zadovoljstvo }\end{array}$ & $\begin{array}{c}\text { Zadovoljstvo } \\
\text { vezom }\end{array}$ \\
\hline Anksiozna privrženost & & $0,24^{* *}$ & $-0,26^{* *}$ & $-0,28^{* *}$ \\
Izbjegavajuća privrženost & $0,25^{* *}$ & & $-0,32^{* *}$ & $-0,36^{* *}$ \\
Seksualno zadovoljstvo & $-0,23^{* *}$ & $-0,34 * *$ & & $0,56^{* *}$ \\
Zadovoljstvo vezom & $-0,35^{* *}$ & $-0,40^{* *}$ & $0,55^{* *}$ & \\
\hline
\end{tabular}

**razina značajnosti $0,01 *$ razina značajnosti 0,05 


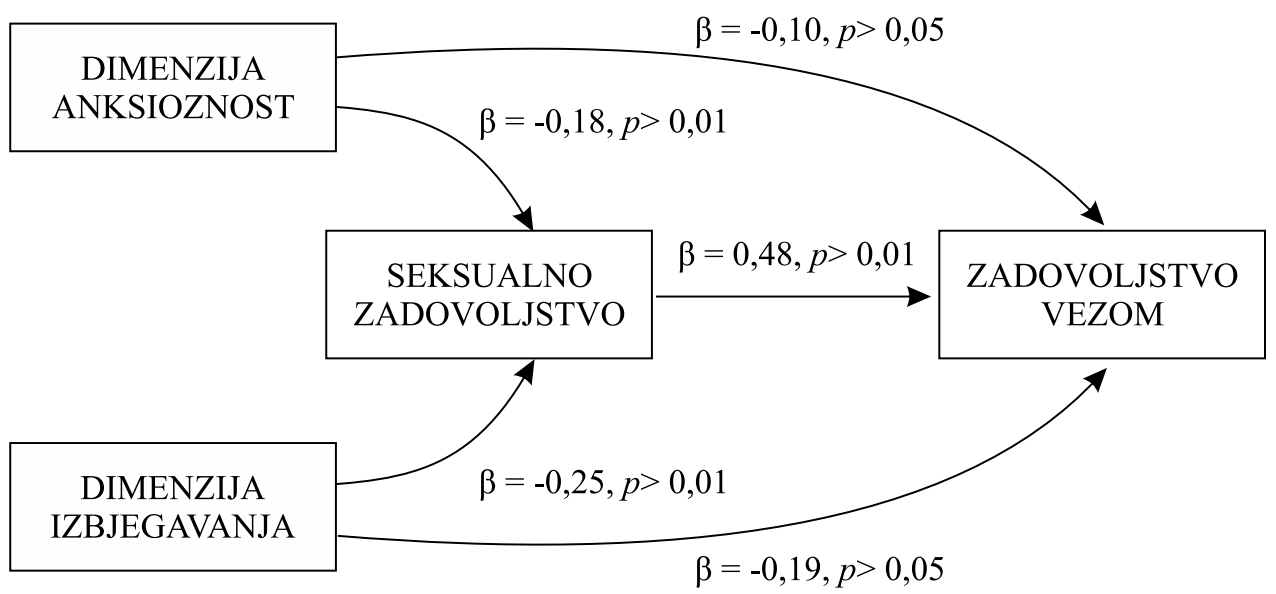

Slika 1. Model odnosa dimenzija privrženosti, seksualnog zadovoljstva i zadovoljstva vezom (muškarci)

značajan doprinos zadovoljstvu vezom kod muškaraca (Slika 1). Nadalje, anksiozna $(\beta=-0,18, p<0,01)$ i izbjegavajuća $(\beta=-0,25, \mathrm{p}<0,01)$ privrženost su prediktori seksualnog zadovoljstva. U trećem koraku je utvrđeno da medijacijska varijabla seksualnog zadovoljstva u značajnoj mjeri predviđa zadovoljstvo vezom $(\beta=0.48$, $\mathrm{p}<0.01$ ). Konačno, u zadnjem koraku, nakon uključenja medijacijske varijable seksualnog zadovoljstva, stupnjevi povezanosti između prediktora anksiozne ( $\beta=$ $-0,09, p>0,05)$ i izbjegavajuće privrženosti $(\beta=-0,12, p>0,05)$ sa zadovoljstvom vezom značajno su se smanjili. Vrijednosti Sobel testa upućuju na statističku značajnost ovog smanjenja $(Z=2,02, p<0,05$ za anksioznu i $Z=3,48, p<0,01$ za izbjegavajuću privrženost). Dakle, seksualno zadovoljstvo doprinosi većem zadovoljstvu vezom, dok dimenzija izbjegavanja doprinosi manjem zadovoljstvu vezom izravno i neizravno, preko smanjenja seksualnoga zadovoljstva. Dimenzija anksioznosti nema značajan izravni doprinos, ali neizravno značajno djeluje na manje zadovoljstvo vezom (Slika 1). Rezultati medijacije pokazuju da su učinci anksiozne i izbjegavajuće privrženosti na zadovoljstvo vezom muškaraca posredovani seksualnim zadovoljstvom.

Regresijskim analizama je utvrđeno da su anksiozna $(\beta=-0.19, \mathrm{p}<0.05) \mathrm{i}$ izbjegavajuća privrženost $(\beta=-0.18, p<0.05)$ značajni prediktori zadovoljstva vezom kod žena (Slika 2). Dalje, anksiozna $(\beta=-0.16, p<0.05)$ i izbjegavajuća $(\beta=$ $-0.32, \mathrm{p}<0.01)$ privrženost prediktori su seksualnog zadovoljstva. U trećem koraku je utvrđeno da medijacijska varijabla seksualnog zadovoljstva u značajnoj mjeri predviđa zadovoljstvo vezom $(\beta=0.43, \mathrm{p}<0.01)$. Konačno, u zadnjem koraku je utvrđeno da se, nakon uključenja medijacijske varijable seksualnog zadovoljstva, stupanj povezanosti između prediktora anksiozne $(\beta=-0.07, \mathrm{p}>0.05)$ i izbjegava- 


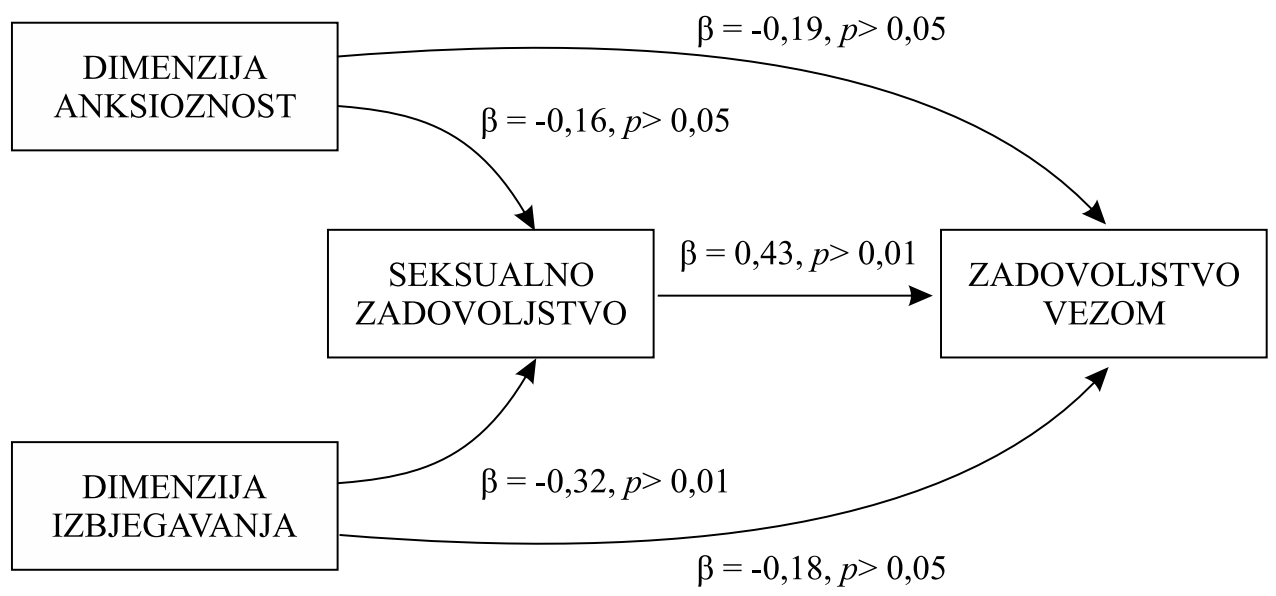

Slika 2. Model odnosa dimenzija privrženosti, seksualnog zadovoljstva i zadovoljstva vezom (žene).

juće privrženosti $(\beta=-0.14, p>0.05)$ sa zadovoljstvom vezom smanjuje i više nije statistički značajan. Vrijednosti Sobel testa upućuju na statističku značajnost ovog smanjenja $(Z=2,8, p<0,01$ za anksioznu i $Z=3,63, p<0,01$ za izbjegavajuću privrženost). Dakle, seksualno zadovoljstvo pozitivno djeluje na zadovoljstvo vezom, dok dimenzije anksioznosti i izbjegavanja negativno djeluju na zadovoljstvo vezom i izravno i neizravno, preko smanjenja seksualnoga zadovoljstva. Rezultati medijacije pokazuju da su učinci anksiozne i izbjegavajuće privrženosti žena na zadovoljstvo vezom posredovani seksualnim zadovoljstvom (Slika 2).

\section{RASPRAVA}

Rezultati ovog istraživanja upućuju na negativnu povezanost anksiozne i izbjegavajuće privrženosti sa seksualnim zadovoljstvom i zadovoljstvom vezom, pri čemu seksualno zadovoljstvo djelomično posreduje između obje dimenzije privrženosti i zadovoljstva vezom kod muškaraca i žena. Izbjegavajuća privrženost kod oba roda ima izraženije učinke na zadovoljstvo vezom u odnosu na anksioznu privrženost. Doprinos anksiozne privrženosti seksualnom zadovoljstvu utvrđen je kod oba roda, a samo kod žena i zadovoljstvu vezom, dok je kod muškaraca taj učinak neizravan, tj. posredovan seksualnim zadovoljstvom.

Sukladno ranijim nalazima (Ayenew, 2016; Li i Chan, 2012), u ovom je istraživanju pronađena negativna povezanost između obje dimenzije privrženosti sa zadovoljstvom u vezi i sa seksualnim zadovoljstvom kod muškaraca i žena. Zadovoljstvo vezom uključuje dinamičan i složen odnos između partnera koji je reguliran 
emocionalnim, kognitivnim i fizičkim aspektima tog odnosa. Stoga nalaz o uzajamnoj povezanosti dimenzija privrženosti, seksualnog zadovoljstva i zadovoljstva vezom koji je utvrđen u ovom istraživanju potvrđuje postojeće znanstvene spoznaje. Razlozi nezadovoljstva vezom anksiozno i izbjegavajuće privrženih proizlaze iz drugačijih kognitivno-emocionalnih obilježja njihova stila privrženosti. Osobe s višim stupnjevima anksiozne privrženosti češće imaju pesimistične atribucije sebe $\mathrm{i}$ ishoda veze, ne vjeruju da su vrijedne ljubavi i žive u strahu od napuštanja od strane partnera. S druge strane, osobe s višim stupnjevima izbjegavajuće privrženosti usmjerene su prema zadržavanju emocionalne neovisnosti i distance u odnosu s partnerom, češće preferiraju površne veze bez dubljeg vezivanja i imaju pesimistične atribucije o partneru i ishodu veze (Collins, Ford, Guichard i Allard, 2006).

U ovom istraživanju utvrđen je posredujući učinak seksualnog zadovoljstva između obje dimenzije privrženosti i zadovoljstva vezom muškaraca i žena. Ovaj nalaz potvrđuje rezultate koje je pronašla Birnbaum (2007) na uzorku žena te upućuje na to da se ovaj nalaz odnosi i na muškarce. Važnost seksualnog zadovoljstva u razumijevanju odnosa između anksiozne privrženosti i zadovoljstva vezom Birnbaum (2007) objašnjava mogućnošću da žene s visokim stupnjevima anksiozne privrženosti koriste seks kao "barometar" kvalitete veze, pri čemu seks poistovjećuju s drugim aspektima romantične veze, kao što su ljubav i brižnost. Iz tog razloga, anksiozna privrženost može pojačati učinke pozitivnih i negativnih seksualnih interakcija na seksualno zadovoljstvo (Birnbaum, 2010). Pozitivne seksualne interakcije mogu privremeno zadovoljiti njihovu stalnu potrebu za sigurnošću i umanjiti intruzivne misli, dok frustrirajuće seksualne interakcije mogu doživjeti kao partnerovo odbacivanje i tako pojačati osjećaj nezadovoljstva u vezi (Birnbaum, 2007). Takvi suprotstavljeni doživljaji seksualnosti mogu rezultirati osjećajima razočaranja u partnerskim (Mikulincer i Shaver, 2007) i seksualnim odnosima (Birnbaum, 2007; Burri, Schweitzer, i O’Brien, 2014). Nadalje, strah od mogućeg odbacivanja od partnera kod anksiozno privrženih ljudi može utjecati na seksualna ponašanja i pristajanja na neželjeni seks, što u konačnici umanjuje seksualno zadovoljstvo (Schachner i Shaver, 2004; Davis, Shaver i Vernon, 2004). Za razliku od rezultata Gurit Birnbaum (2007), u ovom radu seksualno zadovoljstvo posreduje između obje dimenzije privrženosti i zadovoljstva vezom kod muškaraca i žena, pri čemu je neizravni doprinos izbjegavajuće privrženosti na zadovoljstvo vezom čak izraženiji od doprinosa anksiozne privrženosti. Ovaj nalaz je novi empirijski dokaz o negativnom doprinosu izbjegavajuće privrženosti na zadovoljstvo vezom, posredstvom smanjenog seksualnog zadovoljstva. S obzirom na to da osobe s izbjegavajućom privrženosti oba roda često imaju snažne averzivne kognicije spram seksa (Birnbaum i sur., 2006) i tijekom seksa često ne osjećaju užitak, već nelagodu (Khoury i Findlay, 2014), razumljivo je da doživljavaju smanjeno seksualno zadovoljstvo te, neizravno, i smanjeno zadovoljstvo vezom.

Manje izražen negativan učinak anksiozne privrženosti, u odnosu na izbjegavajuću, na seksualno zadovoljstvo koji je pronađen u ovom istraživanju, moguće 
je objasniti dnevnim fluktuacijama u seksualnim iskustvima i odnosima s partnerima anksiozno privrženih ljudi, pri čemu pozitivna seksualna iskustva kratkotrajno umanjuju strah od mogućeg napuštanja te podižu seksualno samopoštovanje i optimizam (Birnbaum, 2010).

Rodne osobitosti u učincima seksualnoga zadovoljstva između dimenzija privrženosti i zadovoljstva vezom

U ovom istraživanju, seksualno zadovoljstvo posreduje između oba stila privrženosti i zadovoljstva vezom kod oba roda. Viši stupnjevi anksiozne privrženosti žena doprinose nižem zadovoljstvu vezom izravno i neizravno, tj. posredstvom smanjenoga seksualnog zadovoljstva. S druge strane, viši stupnjevi anksiozne privrženosti muškaraca doprinose nižem zadovoljstvu vezom samo posredstvom smanjenoga seksualnog zadovoljstva. Ovi rezultati upućuju na značajniji doprinos anksiozne privrženosti na zadovoljstvo vezom žena, dok izbjegavajuća privrženost ima negativan doprinos na zadovoljstvo vezom kod oba roda.

Moguće je da navedene rodne osobitosti proizlaze iz rodnih razlika u seksualnosti. U istraživanju Birnbaum (2007) utvrđeno je da kod anksiozno privrženih žena mogu postoji tendencije izjednačavanja seksa s ljubavlju pa koriste seks za zadovoljavanje ciljeva privrženosti, tj. preveniranje odbacivanja. Nezadovoljstvo seksualnim životom anksiozno privrženih žena može tako doprinijeti nižem zadovoljstvu vezom u cjelini. Međutim, osim seksualnog nezadovoljstva, i drugi rodno specifični čimbenici (primjerice, stalno traženje pažnje od partnera, nesigurnost u vlastitu sposobnost privlačenja partnera, nezadovoljavajuća komunikacija s partnerom, anksioznost i sl.) (Feeney, 1994; Cunningham, Braiker i Kelley, 1982; Fowers, 1991; Acitelli i Antonucci, 1994) mogu izravno utjecati na manje zadovoljstvo vezom žena, u odnosu na muškarce. Moguće je da iz tog razloga viši stupnjevi anksiozne privrženosti žena izravno i neizravno doprinose manjem zadovoljstvu vezom, dok anksiozno privrženi muškarci razdvajaju seksualne i emocionalne aspekte veze (Bogaert i Sadava, 2002), pri čemu seksualno (ne)zadovoljstvo ima veću važnost za zadovoljstvo vezom od zadovoljstva ostalim aspektima veze koji se ne moraju izravno reflektirati na opće nezadovoljstvo svojom partnerskom vezom. U ovom istraživanju izbjegavajuća privrženost ima izravne i neizravne doprinose smanjenom zadovoljstvu vezom kod muškaraca i žena.

Doprinos istraživanja i praktična primjenjivost rezultata

Nalazi ovog istraživanja mogu imati praktičnu primjenjivost u psihološkom tretmanu parova usmjerenog na povećanje seksualnog zadovoljstva i umanjivanje negativnih učinaka nesigurne privrženosti na zadovoljstvo vezom. Iako je psihoterapijskim tehnikama moguće uspješno tretirati probleme u partnerskim odnosima, 
izazov terapijskoj učinkovitosti su situacije kada su seksualni i/ili partnerski problemi povezani s nesigurnom privrženošću koja interferira sa seksualnom izvedbom i ometa postizanje zadovoljstva. Rezultati ovog istraživanja upućuju na potrebu procjene stilova privrženosti i stupnjeva seksualnog zadovoljstva kod oba partnera te primjenu prikladnih tehnika za smanjenje njihovih negativnih učinaka na opće zadovoljstvo vezom.

\section{Ograničenja istraživanja}

Ograničenja ovoga istraživanja vezana su uz metodološke osobitosti koje proizlaze iz nedostataka primijenjene metode "snježne grude" korištene za prikupljanje podataka. Izvor pristranosti ove metode je u karakteristikama početnoga uzorka studenata: njihovi odabiri sudionika nisu slučajni, nego određeni vlastitim karakteristikama i preferencijama. U početnom uzorku dominirali su studenti koji su bili spremniji za suradnju i koji su imali veće osobne društvene mreže, pa su imali veći utjecaj u definiranju uzorka, dok je utjecaj relativno izoliranih pojedinaca bio manji. Nadalje, prilikom uzorkovanja svi su sudionici tretirani kao ista skupina, bez obzira na to jesu li u braku ili izvanbračnoj zajednici. U sljedećim istraživanjima trebalo bi provjeriti razlikuju li se sudionici u ispitivanim obilježjima s obzirom na vrstu partnerske veze. Sljedeće ograničenje odnosi se na primjenu samoopisnih upitnika koji su korišteni u istraživanju, što uključuje nemogućnost provjeravanja istinitosti odgovora i razumijevanja sadržaja čestica od strane ispitanika.

\section{LITERATURA}

Acitelli, L.K. i Antonucci, T.C. (1994). Gender differences in the link between marital support and satisfaction in older couples. Journal of Personality and Social Psychology, 67(4), 688-698.

Ayenew, E. (2016). The Effect of Adult Attachment Style on Couples Relationship Satisfaction. The International Journal of Indian Psychology, 3(2), 50-60.

Birnbaum, G.E. (2007). Attachment orientations, sexual functioning, and relationship satisfaction in a community sample of women. Journal of Social and Personal Relationships, 24, 21-35.

Birnbaum, G.E. (2010). Bound to interact: The divergent goals and complex interplay of attachment and sex within romantic relationships. Journal of Social and Personal Relationships, 27, 245-252.

Birnbaum, G.E., Reis, H.T., Mikulincer, M., Gillath, O. i Orpaz, A. (2006). When sex is more than just sex: Attachment orientations, sexual experience, and relationship quality. Journal of Personality and Social Psychology, 91, 929-943.

Bogaert, A.F. i Sadava, S. (2002). Adult attachment and sexual behavior. Personal Relationships, 9, 191-204. 
Bowlby, J. (1969). Attachment and loss, Vol. 1: Attachment. New York: Basic Books.

Brennan, K.A., Clark, C.L. i Shaver, P.R. (1998). Self-report measurement of adult romantic attachment: An integrative overview. U: J.A. Simpson i W.S. Rholes (Ur.), Attachment theory and close relationships (str. 46-76). New York: Guilford Press.

Burri, A., Schweitzer, R. i O'Brien, J. (2014). Correlates of female sexual functioning: adult attachment and differentiation of self. Journal of Sexual Medicine, 11(9), 2188-2195.

Butzer, B. i Campbell, L. (2008). Adult attachment, sexual satisfaction, and relationship satisfaction: A study of married couples. Personal relationships, 15(1), 141-154.

Collins, N.L., Ford, M.B., Guichard, A.C. i Allard, L.M. (2006). Working models of attachment and attribution process in intimate relationships. Personality and Social Psychology Bulletin, 32, 201-219.

Cunningham, J.D., Braiker, H. i Kelley, H.H. (1982): Marital-status and sex differences in problems reported by married and cohabiting couples. Psychology of Women Quarterly, $6(4), 415-427$

Davis, D., Shaver, P.R., Vernon, M.L. (2004). Attachment style and subjective motivations for sex. Personality and Social Psychology Bulletin, 30, 1076-1090.

Del Giudice, M. (2011). Sex Differences in Romantic Attachment: A Meta-Analysis. Personality and Social Psychology Bulletin, 37, 193-214.

Erickson, B.H. (1979). Some Problems of inference from chain data. Sociological Methodology, 10, 276-302.

Feeney, J.A. (1994): Attachment style, communication patterns and satisfaction across the life cycle of marriage. Personal Relationships, 1(4), 333-348.

Fowers, B.J. (1991). His and her marriage: A multivariate study of gender and marital satisfaction. Sex Roles, 24(3-4), 209-221.

Hazan, C. i Shaver, P.R. (1987). Romantic love conceptualized as an attachment process. Journal of Personality and Social Psychology, 52, 511-524.

Kamenov, Ž. i Jelić, M. (2003). Validacija instrumenta za mjerenje privrženosti u različitim vrstama bliskih odnosa: Modifikacija Brennanova Inventara u bliskim vezama. Suvremena psihologija, 6, 73-91.

Karney, B.R. i Bradbury, T.N. (1995). The longitudinal course of marital quality and stability: a review of theory, method, and research. Psychological Bulletin, 118(1), 3-34.

Kenny, D.A., Kashy, D.A. i Bolger, N. (1998). Data Analysis in Social Psychology. U D. Gilbert, S. Fiske i G. Lindzey (Eds.), The Handbook of Social Psychology (četvrto izdanje, str. 233-265). Boston, MA: McGraw-Hill.

Khoury, C.B. i Findlay, B.M. (2014). What makes for good sex? The associations among attachment style, inhibited communication, and sexual satisfaction. Journal of Relationships Research, 5(7), 1-11.

Lawrance, K. i Byers, E.S. (1995). Sexual satisfaction in long-term heterosexual relationships: The Interpersonal Exchange Model of Sexual Satisfaction. Personal Relationships, 2, 267-85.

Li, T. I Chan, D.K.-S. (2012). How anxious and avoidant attachment affect romantic relationship quality differently: A meta-analytic review. European Journal of Social Psycho$\log y, 42,406-419$. 
Little, K.C., McNulty, J.K. i Russell, V.M. (2010). Sex buffers intimates against the negative implications of attachment insecurity. Personality and Social Psychology Bulletin, 36(4), 484-498.

MacNeil, S. i Byers, E.S. (2005). Dyadic assessment of sexual self-disclosure and sexual satisfaction in heterosexual dating couples. Journal of Social and Personal Relationships, 22(2), 169-181.

Mark, K., Milhausen, R. i Maitland, S. (2013). The impact of sexual compatibility on sexual and relationship satisfaction in a sample of young adult heterosexual couples. Sexual and Relationship Therapy, 28, 201-214.

Mikulincer, M. i Shaver, P.R. (2007). Attachment in adulthood: Structure, dynamics, and change. New York, London: Guilford Press.

Milad, H.E., Ottenberger, R.D. i Artigas, H.D. (2014). Associations among attachment, sexuality, and marital satisfaction in adult Chilean couples: a linear hierarchical models analysis. Journal of Sex and Marital Therapy, 40(4), 259-274.

Péloquin, K., Brassard, A., Delisle, G. i Bédard, M.M. (2013). Integrating the attachment, caregiving, and sexual systems into the understanding of sexual satisfaction. Canadian Journal of Behavioural Science, 45(3), 185-195.

Russell, V.M., Baker, L.R. i McNulty, J.K. (2013). Attachment Insecurity and Infidelity in Marriage: Do Studies of Dating Relationships Really Inform Us about Marriage? Journal of Family Psychology, 27(2), 242-251.

Schachner, D.A. i Shaver, P.R. (2004). Attachment dimensions and motives for sex. Personal Relationships, 11, 179-195.

Sprecher, S. i Cate, R. (2004). Sexual satisfaction and sexual expression as predictors of relationship satisfaction and stability. U: Harvey, J., Wenzel, A. i Sprecher, S. (Ur.), Handbook of sexuality in close relationships: 235-256. Mahwah, NJ: Lawrence Erlbaum.

Štulhofer, A. i Buško, V. (2008). Evaluacija novog instrumenta za procjenu seksualnog zadovoljstva. Suvremena psihologija, 11, 287-312.

Yeh, H.C., Lorenz, F.O., Wickrama, K.A., Conger, R.D. i Elder, G.H. (2006). Relationships among sexual satisfaction, marital quality, and marital instability in midlife. Journal of Family Psychology, 20, 339-343. 


\title{
THE MEDIATING ROLE OF SEXUAL SATISFACTION BETWEEN ATTACHMENT DIMENSIONS AND RELATIONSHIP SATISFACTION
}

\begin{abstract}
The Modified Inventory of Experiences in Close Relationships (Kamenov and Jelić, 2003) and the New Scale of Sexual Satisfaction (Štulhofer and Buško, 2008) were applied on a convenience sample of 255 male and 257 women using the "snow ball" method. The results indicated a significantly higher level of anxious attachment in women and to significantly higher level of avoidant attachment in men. Both dimensions of attachment are negatively associated with both sexual and relationship satisfaction, whereby the mediating effect of sexual satisfaction between attachment dimension and relationship satisfaction has been established. The avoidance dimension has shown a more pronounced effect on sexual satisfaction in both sexes, while dimension of anxiety had the direct effect only to the relationship satisfaction of women.
\end{abstract}

Keywords: sexual satisfaction; relationship satisfaction; attachment

Primljeno: 15. 07. 2018 